https://jurnal.unigal.ac.id/index.php/jall/index

ISSN: 2598-8530

February 2018, Vol. 2 No. 1

English Education Program

Faculty of Teacher Training and Education

Galuh University

\begin{tabular}{|ccc|}
\hline Received: & Accepted: & Published: \\
\hline October 2017 & December 2017 & February 2018 \\
\hline
\end{tabular}

\title{
MOVES ANALYSIS OF APPLICATION LETTERS WRITTEN BY AGRIBUSINESS STUDENTS \\ (A DESCRIPTIVE STUDY AT ESP CLASS)
}

\author{
Dedeh Rohayati \\ dedehrohayati@gmail.com \\ Faculty of Agriculture, Galuh University, Ciamis, Indonesia
}

\begin{abstract}
This study aimed at 1) analyzing moves of Application Letter written by Agribusiness students; and 2) language used in Application Letter. The study adopted the descriptive research involving the third semester students at Agribusiness Department of Agriculture Faculty in a Private University in East Priangan, West Java. The selected participants were 18 students who were asked to write Application Letter (solicited letter); and those document texts were analyzed, particularly, in term of the move structure referring to previous study conducted by Bhatia (1993), Henry and Roseberry (2001), Khan \& Tin (2012), and Wijayanti (2017), by using quantitative and qualitative descriptive method. Therefore, the present study provided evidence for description of moves in Application Letter written by Agribusiness students. It consisted of fourteen moves: opening salutation, referring to source information, stating reason, offering candidature, introducing candidature, promoting candidature, offering candidature, glorifying institution, enclosing document, willingness to action, stressing the fact, offering to provide information, thanking, and closing salutation. However, the move structure was weakened by their inability in producing effective and impressive language used in Application Letter; they still need improving in language aspect such as expression, cohesive, coherence, and spelling. This resulted in necessity of an explicit teaching in writing professional genre of Application Letter for Agribusiness students. Further research is recommended to investigate the related topic in terms of language aspect.
\end{abstract}

Key words: Agribusiness Students, Application Letter, ESP, Moves Analysis 


\section{INTRODUCTION}

Application Letter is one of genre focusing on the text relating to the professional context (Bhatia, 1993, 2012; Hayland, 2012). Swales (1990) and Bhatia (1993) described genre as a category of communication events which are characterized by some sets of communication purposes. The ability to write a genre of application letter in university students is overwhelmingly needed because it can become ultimate equipment for them in applying for a job in the future. Therefore, the university students, in particular at Agribusiness Department of Agriculture Faculty, should be equipped by the sufficient knowledge of how to write an impressive and effective Application Letter.

The Application Letter is established by the structure of moves "applied in one sentence or more, or even in one clause of phrase" (Swales, 1990). The several moves and steps of writing an Application Letter were proposed by several experts such as Bhatia (1993), Henry \& Roseberry (2001), and Khan \&Tin (2012), On contrary to former researchers aforementioned, Wijayanti (2017) reports the general moves of the application letters in Indonesian context which consist of 15 moves.

Due to the beneficial value of Application Letter, many researchers had a great intention to carry out the research on related topic. By focusing on move analysis of Application Letter, Tatsanajamsuk (2017) following Bhatia (1993), Mohamed et all (2017)

referring to Henry \& Roseberry (2001) and Khan \& Tin (2012), and Wijayanti (2017) reports the most important moves and compulsory moves embraced in Application Letter. Of all three previous studies were carried out to analyze Application Letter written by professional individual. In contrary, the study emphasizes the Application Letter written by non-English students majoring Agribusiness carrying out in the present study is still limited. To fill this gap, the current study focuses on revealing the moves realized in Application Letter written by Agribusiness students and language used in Application Letter.

\section{METHOD}

This study employed both quantitative and qualitative method. The data were Application letters written by the eighteen students of third semester at Agribusiness Department of Agriculture Faculty. The students were required to write Application Letter based on the resources (solicited letter), i.e. an advertisement of job vacancy from a newspaper. Subsequently, these data were analyzed quantitatively and qualitatively. Quantitatively, the content analysis was conducted to identify moves established in Application Letter by using Bhatia (1993), Henry \& Roseberry (2001), Ran \& Khan (2012), and Wijayanti (2017). Second step was to count the frequency and put the percentage 
occurrence of each moves of Application Letter into the table. The last was to depict the language used in Application Letter written by Agribusiness students descriptively.

\section{FINDINGS AND DISCUSSION}

A total of 14 moves were identified in all 18 job letters as can be seen in Table 2 following previous study conducted by Bhatia (1993), Henry and Roseberry (2001), Khan and Tin (2012), and Wijayanti (2017).

Table 2: Moves and steps in the letters

\begin{tabular}{|l|l|c|c|}
\hline No. & \multicolumn{1}{|c|}{ Moves (M) } & $\begin{array}{c}\text { Frequency } \\
\mathbf{N = 1 8}\end{array}$ & $\begin{array}{c}\mathbf{N}=\mathbf{( 8 )} \\
(\%)\end{array}$ \\
\hline 1. & Opening salutation & 18 & 100 \\
\hline 3. & Referring to source information & 16 & 89 \\
\hline 4. & Stating reason & 2 & 11 \\
\hline 5. & Offering candidature & 15 & 83 \\
\hline 6. & Promoting candidature & 15 & 83 \\
\hline 7. & Offering preferences & 15 & 83 \\
\hline 8. & Glorifying institution & 2 & 33 \\
\hline 9. & Enclosing document & 4 & 22 \\
\hline 10. & Willingness to action & 16 & 89 \\
\hline 11. & Stressing the fact & 5 & 28 \\
\hline 12. & Offering to provide information & 2 & 11 \\
\hline 13. & Thanking & 12 & 67 \\
\hline 14. & Closing salutation & 18 & 100 \\
\hline
\end{tabular}

The Table 2 above suggests that there are fourteen moves in Application Letter written by Agribusiness students: opening salutation, referring to source information, stating reason, offering candidature, introducing candidature, promoting candidature, offering candidature, glorifying institution, enclosing document, willingness to action, stressing the fact, offering to provide information, thanking, and closing salutation. The move of opening salutation and closing salutation posted the first rank of all in Table 2 which covered $100 \%$; followed by referring to source information and willingness to action (89\%). Meanwhile, offering candidature, introducing candidature, promoting candidature had a similar frequency (83\%), and followed thanking (67\%). Regarding moves that were less than 50\%, it showed the 
students' ability in elaborating the messages in order to produce an impressive Application Letter.

These moves also can be identified in the framework of move scheme (see Table 1) stated by Bhatia (1993), Henry and Roseberry (2001), Khan \& Tin (2012) and Wijayanti (2017). Comparing to Wijayanti (2017), the present study did not utilize praying for employer and offering service (see Table 3). However, there were some moves which have different terms but they have similar purpose with this study. For example, Khan \& Tin (2012) named addressing for opening salutation; stating availability (Henry \& Roseberry , 2001) is similar to offering preferences; willingness to action was named for this study but Bhatia (1993) called it soliciting response; meanwhile welcoming response was used by Henry \& Roseberry (2001). Besides, the naming of thanking was called ending politely by Bhatia (1993); also, closing with courtesy was used by Khan \& Tin (2012) to name closing salutation in this study.

By referring to Table 3, also, the moves revealed in this study and previous research are universal that can be used as a guideline in writing Application Letter. It comprises 1) opening salutation (addressing), 2) referring to source information, 3) offering candidature, 4) promoting candidature, 5) enclosing document, 6) willingness to action (soliciting response, welcoming response), 7) thanking (ending politely, closing with salutation). This finding was in line with what has been found by Wijayanti (2017). It was reasonable because the present study was conducted in Indonesian context.

Regarding the second research question, the language used in Application Letter, it was found that the students were able to establish each move by using the appropriate language used. Although the expressions were lack of cohesive and coherence device, and poor of spelling, they established the moves by applying one sentence or more and one clause of phrase as suggested by (Swales, 1990). For example, the phrase of Dear Sir/ Madam was commonly used by students in opening salutation. The students also commenced the move of refer to the information source by using the following phrase:

Based on the information...

Referring to the information... I am responding to ....

Referring to your requirement advertised in.... 
Table 3: The Differences of the Current Study and the Previous Studies

\begin{tabular}{|c|c|c|c|c|c|}
\hline Moves (M) & $\begin{array}{l}\text { Bhatia } \\
\text { (1993) }\end{array}$ & $\begin{array}{c}\text { Henry and } \\
\text { Roseberry } \\
\text { (2001), }\end{array}$ & $\begin{array}{c}\text { Khan and } \\
\text { Tin } \\
\text { (2012) }\end{array}$ & $\begin{array}{c}\text { Wijayanti } \\
\text { (2017) }\end{array}$ & $\begin{array}{c}\text { Current } \\
\text { study }\end{array}$ \\
\hline Opening salutation & & $\sqrt{ }$ & Addressing & $\sqrt{ }$ & $\sqrt{ }$ \\
\hline $\begin{array}{l}\text { Referring to source } \\
\text { information }\end{array}$ & & $\sqrt{ }$ & $\sqrt{ }$ & $\sqrt{ }$ & $\sqrt{ }$ \\
\hline Stating reason & & V & & $\sqrt{ }$ & $\sqrt{ }$ \\
\hline Offering candidature & $\checkmark$ & $\sqrt{ }$ & $\sqrt{ }$ & $\sqrt{ }$ & $\sqrt{ }$ \\
\hline Introducing candidature & $\sqrt{ }$ & & & $\sqrt{ }$ & $\sqrt{ }$ \\
\hline Promoting candidature & & $\sqrt{ }$ & & $\sqrt{ }$ & $\sqrt{ }$ \\
\hline Offering preferences & & $\begin{array}{l}\text { Stating } \\
\text { availability }\end{array}$ & & $\sqrt{ }$ & $\sqrt{ }$ \\
\hline Glorifying institution & & & $\sqrt{ }$ & $\sqrt{ }$ & $\sqrt{ }$ \\
\hline Enclosing document & $\checkmark$ & $\sqrt{ }$ & $\sqrt{ }$ & $\sqrt{ }$ & $\sqrt{ }$ \\
\hline Willingness to action & $\begin{array}{l}\text { Soliciting } \\
\text { response }\end{array}$ & $\begin{array}{l}\text { welcoming } \\
\text { response }\end{array}$ & $\begin{array}{l}\text { Soliciting } \\
\text { response }\end{array}$ & $\sqrt{ }$ & $\sqrt{ }$ \\
\hline Stressing the fact & & & & $\sqrt{ }$ & $\sqrt{ }$ \\
\hline $\begin{array}{l}\text { Offering to provide } \\
\text { information }\end{array}$ & & V & $\sqrt{ }$ & & $\sqrt{ }$ \\
\hline Thanking & $\begin{array}{l}\text { Ending } \\
\text { politely }\end{array}$ & $\sqrt{ }$ & $\sqrt{ }$ & $\sqrt{ }$ & $\sqrt{ }$ \\
\hline Closing salutation & & & $\begin{array}{l}\text { Closing with } \\
\text { courtesy }\end{array}$ & $\sqrt{ }$ & $\sqrt{ }$ \\
\hline
\end{tabular}

With regards to offering the candidature, students were very common to use:

..., so I hereby submit myself to fill the position..;

I would like to apply as an ... Herewith I am applying for a job in ...

..., so with this I volunteered to fill the position.

To introduce candidature, the students employed the phrase of:

I undersigned below:..

For your consideration, I have attached a curriculum vitae below:...

My identity is as follow:.... 
Meanwhile, in promoting candidature, while leading the recruiter to the curriculum vitae, the students commonly used the expressions in a paragraph, for example:

"I have completed my undergraduate program in the field of management from Galuh University. I have over 4 years experiences as an administrator at Santika Hotel. Then, I also gave 3 years experiences as an Assistant Manager at Pajajaran Hotel. I may inform you that I have some skills; besides I also speak English very well and is able to operate a computer and the internet properly".

The other three obligatory moves were willingness to action, thanking, and closing salutation. The move of willingness to action was commonly represented in the expressions of " $I$ am looking forward to the interview/ to hearing from you soon”. Dealing with thanking, students utilized the expressions below:

...I say thank you for the attention.

... I say many thanks.

Thank you for your consideration

The Application Letter were ended by closing salutation at which the commonly phrases used were Your sincerely, Best regards, With respect, Respectfully, Your faithfully.

\section{CONCLUSIONS}

The Application Letter should be written persuasively because it promotes the applicants themselves. Thus, job applicants have to be creative in presenting their qualification very well by using impressive and effective language. Application Letter written by Agribusiness students contains the fourteen moves: opening salutation, referring to source information, stating reason, offering candidature, introducing candidature, promoting candidature, offering preferences, glorifying institution, enclosing document, willingness to action, stressing the fact, offering to provide information, thanking, and closing salutation. However, the move structure was weakened by their inability in expressing idea or language used which leads to the necessity of improving their knowledge in linguistic feature, in particular, in using cohesive and coherence device. This implies that the Agribusiness students need an explicit teaching of how to write a genre of Application Letter. The result of this study contributes to the improvement of effective teaching writing in ESP class because writing professional genre, in particular, Application Letter is beneficial in finding a good job. Since the ability of linguistic feature of Application Letter is a predominant factor in genre, future research involving language aspects (expression, spelling, sentence, paragraph, cohesion, and coherence) are recommended to be investigated. 


\section{REFERENCES}

Bhatia, V.K.(2012). Critical reflections on genre analysis. Ibérica 24 (2012): 17-28, hal.17-27 (http://www.aelfe.org/documents/03_24_Bhatia.pdf, 5 Juni 2017)

Bhatia, V.K. (On Vijay K. Bhatia: Analysing Genre: Language Use in Professional Settings (1993)

Henry, A., \& Roseberry, R. L. (2001). A Narrow-Angled Corpus Analysis of Moves and Strategies of the Genre: 'Letter of Application. English for Specific Purposes, 20, 153 167.

Khan, A. and Tin, T.B. (2011). Generic patterns in application letters: the context of Pakistan. RELC Journal 43(3) $393-410$.

Mohamed, N., Halim, N.S., Husin, N., and Mokhtar, N. (2017). An analysis of promotional genre in job application letters. e-Academia Journal (http://journaleacademiauitmt.edu.my/) (C) Universiti Teknologi MARA Terengganu Volume 6 Issue 1 2017, 58 - 69.

Swales, J. M. (1990). Genre Analysis English in Academic and Research Settings. Cambridge: Cambridge University Press.

Tatsanajamsuk, P. (2017). Genre analysis in letter of application and syllabus design. Online Proceedings of the International Conference: DRAL 3/19th ESEA 2017, p.201-304

Wijayanti, S.H. (2017). The moves of Indonesian application letters. Lingua Cultura, 11(1), May 2017, 39-45, p. 39-45

https://cih.wikispaces.com/file/view/Cover_letter_genre.pdf, 27th September 2017

https://www.agronomy.org/files//publications/nse/pdfs/jnr005/005-01-0073.pdf 27 September 2017 